\title{
Description of a New Melithreptus from Western Australia.
}

By A. W. Milligan, Perth.

DURING an expedition undertaken by myself, in conjunction with Dr. Morrison, the Government Botanist, and Mr. Conigrave, of the Perth Museum, in the Stirling Ranges, in the south-east portion of this State, I shot three Honey-eaters in the flowering scrubs at the foot of Mount Mongerup. They appeared at first sight to be the Brown-headed Honey-eater, Melithreptus brevirostris, Vig. and Hors, although. I perceived, as I thought, differences from that species.

On my return to Perth I borrowed from Mr. A. G. Campbell, Melbourne, a skin of M. brevirostris shot at Myrniong, in Victoria, and subsequent comparison with that bird and with the descriptions given by Gould and the British Museum Catalogue proved that my first perceptions were not altogether erroneous.

For the purposes of comparison it will perhaps be as well to give a specific description of three birds shot, and in which there is not any appreciable difference in any respect except that two were males, one a female. The description is as follows :-

Crown and sides of head blackish-grey-an occipital band from eye to cyc, such band being distinct and white from eye to back of ear-covert, but only faintly perceptible, and impure white for the remainder. Below this band another parallel one, extending from ear-covert to ear-covert-the latter band being distinct and blackish-grey at beginning, but only faintly perceptible for the remainder; mantle, back, and upper tail coverts olive-yellow, like $M$. chloropsis, but with less yellow and not so intense; wings blackish-brown, edged with white; tail feathers blackishbrown externally washed with same colour as back; cheeks and sides of throat pure white, contrasting with blackish sides of head, and with the chin, middle of throat, and chest, which are respectively blackish, shading into ashy-grey ; breast, abdomen, and under tail coverts a shade between cream and impure white, the colour deepening on abdomen and under tail coverts : axillaries and shoulder edges and remiges white, a little crean colour showing in places; bare spaces surrounding the eye a light orange colour, excepting lower portion of eyelid below the orange zone, which shows bluish-emerald; bill dark brown, legs and feet reddish orange. Total length, 5.25; wing, 2.7; tail, 2.0 ; tarsus, .65 ; culmen, .4 .

The Victorian bird corresponded with the descriptions in the British Museum Catalogue, but not with the western species.

The specific differences between them, briefly summarized, are - (a) the new bird is less robust generally, and the bill in particular is shorter and more slender; $(\delta)$ the bare spaces sprrounding the eye are orange and bluish-emerild; $(c)$ the 
blackish chin is distinctly marked, as also the greyish breast; (d) the cheeks are white; and (e) the head is blackish brown. I therefore assign to the new bird the scientific name of Melithreptus lencogenys, and the vernacular name of the Western Brown-headed Honey-eater. 